\title{
Plasma Thyroid Hormones and Prolactin in Premature Infants and Their Mothers after Prenatal Treatment with Thyrotropin-Releasing Hormone
}

\author{
PHILIP L. BALLARD,' ROBERTA A. BALLARD, ${ }^{1}$ ROBERT K. CREASY, JAMES PADBURY, \\ DANIEL $H$. POLK, MICHAEL BRACKEN, FERNANDO R. MOYA, ${ }^{2}$ AND IAN GROSS ${ }^{3}$ \\ Department of Pediatrics and Obstetrics and Gynecology, Mount Zion Hospital and Medical Center and the \\ University of California, San Francisco, California 94143; Yale University Schools of Medicine and \\ Epidemiology and Public Health, New Haven, Connecticut 06510; University of Texas Health Science Center, \\ Houston, Texas 77030; Harbor Medical Center-University of California \\ Los Angeles, Torrance, California 90509
}

\begin{abstract}
We assayed TSH, triiodothyronine, free thyroxine, and prolactin (PRL) in plasma of women and infants participating in a trial of prenatal thyrotropin-releasing hormone (TRH) treatment for prevention of newborn lung disease. Women in labor at 26-34 wk of gestation received $400 \mu \mathrm{g}$ of TRH i.v. every $8 \mathrm{~h}$ (one to four doses) plus 12 mg betamethasone (one or two doses); controls received saline plus betamethasone. Mean cord concentrations in control infants were TSH $9.7 \mathrm{mU} / \mathrm{L}$, triiodothyronine 0.6 $\mathrm{nmol} / \mathrm{L}(40.2 \mathrm{ng} / \mathrm{dL})$, free thyroxine $14.4 \mathrm{pmol} / \mathrm{L}(1.13 \mathrm{ng} /$ dL), and PRL $67.6 \mu \mathrm{g} / \mathrm{L}$. TRH increased maternal plasma TSH by $100 \%$ at $2-4 \mathrm{~h}$ after treatment and decreased levels by $28-34 \%$ at 5-36 h. In cord blood of treated infants delivered at 2-6 h, TSH, triiodothyronine, and PRL were all increased about 2 -fold versus control, and free thyroxine was increased 19\%; the response was similar after one, two, three, or four doses of TRH. In treated infants delivered at 13-36 h, cord TSH and triiodothyronine levels were decreased 62 and $54 \%$, respectively, and all thyroid hormones were lower after birth at $2 \mathrm{~h}$ of age versus control. We conclude that prenatal TRH administration increases thyroid hormones and PRL in preterm fetuses to levels similar to those normally occurring at term. Pituitary-thyroid function is transiently suppressed after treatment to a greater extent in fetus than mother, and infants born during the early phase of suppression do not have the normal postnatal surge in thyroid hormones. (Pediatr Res 32: 673-678, 1992)
\end{abstract}

Received March 30, 1992; accepted August 7, 1992

Correspondence: Philip L. Ballard, M.D., Ph.D., Division of Neonatology, Room 8073, The Children's Hospital of Philadelphia, 34th Street and Civic Center Blvd., Philadelphia, PA 19104

Supported by grants from the National Institutes of Health (HL 24075), March of Dimes-National Foundation; Mount Zion General Research Support; Perinatal Associates, Inc.; Yale Children's Clinical Research Center (NIH M01 RR00125); and GCRC-RR-00425. The TRH (Thypinone, Abbott) for this study was provided by Abbott Laboratories North Chicago, IL

'Present address: Neonatology, Department of Pediatrics, Children's Hospital of Philadelphia, 34th St. and Civic Center Blvd., Philadelphia, PA 19104.

${ }^{2}$ Present address: Neonatal-Perinatal Medicine, University of Texas Southwestern Medical Center, 5323 Harry Hines Blvd., Dallas, TX 75235.

${ }^{3}$ Other participants of the TRH Study Group: Mount Zion: Ronald I. Clyman, M.D., Deborah J. Davis, M.D., Carlos Garcia, M.D., Amnon Goodman, M.D., Denise M. Main, M.D., D. Douglas Henning, M.D., Marie A. Herron, R. N., Helen G. Liley, M.D., Robert E. Piecuch, M.D., Robert S. Roth, M.D., Sally A. Sehring, M.D and Susan H. Sniderman, M.D Yale: Linda Leo Summers, M.P.H., Richard A. Ehrenkranz, M.D., E. Albert Reece, M.D., I. M. Gladstone, M.D., and Patricia A. Gettner, R.N. Harbor-UCLA: Michael G. Ross, M.D., Sarah Alvarez, R.N., and Christine Mori, R.N. University of Texas, Houston: Sue M. Palmer, M.D., Cheryl M. Robinson, M.D., Jose Garcia, M.D., and Patricia Tomek, R.N., B.S.N.

\section{Abbreviations}

RDS, respiratory distress syndrome TRH, thyrotropin-releasing hormone PRL, prolactin

$\mathrm{T}_{3}$, triiodothyronine

$T_{4}$, thyroxine

Antenatal glucocorticoid therapy decreases the incidence of RDS and several other complications of preterm birth. Although this treatment is efficacious and safe, it does not always prevent RDS, and infants of very low birth weight often develop chronic lung disease. Recent efforts to improve the efficacy of prenatal preventive therapy have assessed effects of thyroid hormones.

Treatment with thyroid hormones has additive or synergistic effects with glucocorticoids in stimulating lung development in animals and cultured tissue, and endogenous $T_{3}$ appears to have a role in normal maturation (1-12). Earlier studies in humans used intraamniotic administration of $\mathrm{T}_{3}$ or $\mathrm{T}_{4}$ in an attempt to accelerate fetal lung maturation (13-14). More recently, clinical studies have used maternal treatment with TRH, a tripeptide that readily crosses the placenta (15-19). Although levels of thyroid hormones and PRL have been described for TRH-treated fetuses at term, there is relatively little information on hormone responses in premature infants.

A collaborative trial of prenatal administration of TRH plus glucocorticoid was carried out to determine whether this combined therapy would be more effective than glucocorticoid alone in reducing the incidence and severity of lung disease and other problems of the very low birth weight infant. The results of this trial, which were recently published (20), indicated that significantly fewer TRH-treated infants developed chronic lung disease (requirement for supplemental oxygen at $28 \mathrm{~d}$ of age or $36 \mathrm{wk}$ postconception). In this article, we report our findings for plasma concentrations of thyroid hormones and PRL in women and infants who were enrolled in the collaborative trial. We describe the stimulation and subsequent suppression of thyroid function after TRH treatment. Preliminary findings have been previously reported $(20,21)$.

\section{MATERIALS AND METHODS}

Patient population. The plasma samples analyzed in this study were obtained from women and their infants enrolled in a 
multicenter, blinded, randomized, placebo-controlled trial of prenatal TRH therapy (19). The TRH treatment group $(n=99)$ received $400 \mu \mathrm{g}$ of TRH administered i.v. in $50 \mathrm{~mL}$ of saline during a 20-min infusion; unless delivery occurred, treatment was repeated at 8 -h intervals for a total of four doses. In addition, the women received two doses of betamethasone (Celestone Soluspan, Schering Corp., Kenilworth, NJ) 12 mg intramuscularly given $12 \mathrm{~h}$ apart. The control group $(n=105)$ received 50 $\mathrm{mL}$ of normal saline (placebo) during a 20 -min infusion, every $8 \mathrm{~h}$ for up to four doses, and betamethasone was administered on the same schedule as in the TRH group. The study was approved by human experimentation committees at each institution.

Assays. Samples of maternal venous, umbilical venous, and umbilical arterial blood were collected at delivery from patients who delivered $\leq 10 \mathrm{~d}$ after entry into the trial. In addition, blood samples were taken from an umbilical arterial catheter or peripheral vein from newborn infants at $2 \mathrm{~h}$ and approximately $24 \mathrm{~h}$ of age. Plasma was obtained by centrifugation and stored at $-70^{\circ} \mathrm{C}$

RIA for TSH, $\Upsilon_{3}$, free $\mathrm{T}_{4}$, and PRL were performed in duplicate on the samples. When there was limited plasma volume, priority was given to assay of TSH and free $\mathrm{T}_{4}$. The RIA kits for TSH, free $\mathrm{T}_{4}$, and PRL were obtained from Becton Dickinson (Orangeburg, NY) and had sensitivity and interassay coefficient of variation values of $0.2 \mathrm{mU} / \mathrm{L}$ and $7.4 \%, 0.1 \mathrm{pmol} / \mathrm{L}$ and $4.5 \%$, and $1 \mu \mathrm{g} / \mathrm{L}$ and $6.1 \%$, respectively. The $\mathrm{T}_{3}$ assay kit was purchased from Corning Medical (Medfield, MA) and had sensitivity and interassay coefficients of variation values of 0.1 $\mathrm{nmol} / \mathrm{L}$ and $5.8 \%$, respectively. The volume of all samples was adjusted to give results in the linear range of the assay. Repeated assays of selected samples indicated that there was no effect of storage time on the hormone concentrations. For individual cord umbilical samples, results for venous and arterial plasma were similar for each of the assays.

Data analysis. All of the assays and analyses were performed in a blinded fashion before the treatment code was broken. In the case of cord umbilical samples, the mean value for arterial and venous specimens was used in the final data analysis, which was limited to pregnancies of 26-34 wk of gestation in which delivery occurred within $10 \mathrm{~d}$ of the last dose of TRH. Results for the treated group were evaluated by the interval from the last dose of TRH to delivery (see Results), and data were compared with the control population. Based on the observed time course of hormone concentrations in individual infants, we used an initial interval after the last dose of TRH of 2-4 h for TSH and 2-6 $\mathrm{h}$ for $\mathrm{T}_{3}$, free $\mathrm{T}_{4}$, and PRL. The concentrations of hormones in the control samples did not vary with time from last dose of placebo ( $2 \mathrm{~h}$ to $10 \mathrm{~d}$ ), and a mean value for the entire group was used in the comparisons. Mean \pm SEM values are presented, and statistical comparisons were made using analysis of variance with Bonferroni adjustment for multiple comparisons, linear regression, and unpaired $t$ tests.

\section{RESULTS}

Control group. We limited our analysis to control and treated infants of $\leq 34$ wk gestation who delivered $\leq 10 \mathrm{~d}$ after entry into the trial and for whom blood samples were collected. The mean gestational age for control infants $(n=62)$ was $29.6 \mathrm{wk}$, and the distribution of infants by gestational age was comparable to the TRH-treated population $(n=71$, mean $30.0 \mathrm{wk})$. There were no significant differences between control and treated infants for incidence of RDS, intracranial hemorrhage, patent ductus arteriosus, necrotizing enterocolitis, or for Apgar scores.

The control women and their fetuses were all treated with betamethasone; however, there was no effect of the treatment interval (last dose to delivery) on maternal or cord hormone concentrations (data not shown), suggesting that corticosteroid therapy did not affect the concentration of thyroid hormones or
PRL. Table 1 summarizes mean concentrations of hormones in maternal and infant plasma for the control group. The data are similar to previously described results and confirm differences in hormone concentrations between cord and maternal plasma as well as the postnatal surge in TSH and thyroid hormones (22). There was a significant positive correlation with gestational age for PRL between 26 and $34 \mathrm{wk}(r=0.34, p<0.001)$ and nonsignificant trends for $\mathrm{T}_{3}$ and free $\mathrm{T}_{4}$. There were no gestationdependent changes in concentrations of maternal hormones.

Maternal concentrations after TRH. Figure 1 shows concentrations of plasma TSH and $\mathrm{T}_{3}$ in TRH-treated women at delivery. Compared with controls, TSH was elevated approximately 2 fold $(p<0.05)$ in women who received the last dose of TRH 2$4 \mathrm{~h}$ before delivery (Fig. $1 \mathrm{a}$ ). For women delivering 5-36 h after the last TRH treatment, TSH concentrations were slightly decreased (66-72\% of control, NS after adjusting for multiple comparisons).

Maternal concentrations of $\mathrm{T}_{3}$ were increased after TRH treatment but reached statistical significance only for those women delivering $13-24 \mathrm{~h}$ after the last dose $(+57 \%)$. In women delivering at later times, levels of $\mathrm{T}_{3}$ were not different from control (Fig. 1b). Plasma concentrations of free $\mathrm{T}_{4}$ (data not shown) were higher in treated women delivering up to $36 \mathrm{~h}$ after the last dose of TRH (range at different time intervals 13.3-14.2 pmol/L versus control $11.2 \pm 0.5 \mathrm{pmol} / \mathrm{L}, \mathrm{NS}$ after adjusting for multiple comparisons); values at the two later time intervals were not significantly different from control. Maternal concentrations of PRL were decreased $\sim 40 \%$ in women delivering 2-6 $\mathrm{h}$ after the last dose of TRH (71.8 $\pm 15 \mu \mathrm{g} / \mathrm{L}, \mathrm{NS}$ after adjusting for multiple comparisons) but were not different from control at later time intervals.

Cord concentrations after TRH. Figure 2 shows the time course for concentrations of thyroid hormones and PRL in cord plasma. Maximal levels of TSH $(18.8 \pm 2.5 \mathrm{mU} / \mathrm{L}, n=9)$ occurred at 2-4 $\mathrm{h}$ after the last dose of TRH and were nearly double the control level (Fig. 2a). At 5-6 h (not shown), the TSH concentration was similar to control $(8.25 \pm 1.57 \mathrm{mU} / \mathrm{L})$, and by $13-$ $24 \mathrm{~h}$, the level was significantly decreased (38\% of control). TSH values increased progressively at later time intervals and were similar to control at 49-240 h after the last dose.

The concentration of $T_{3}$ in cord plasma of 2- to 6-h treated infants $(1.2 \pm 0.2 \mathrm{nmol} / \mathrm{L}, n=9)$ was increased approximately 2 -fold versus control (Fig. $2 b$ ). Levels at subsequent intervals decreased progressively, reaching $0.3 \mathrm{nmol} / \mathrm{L}$ ( $46 \%$ of control, $p$ $<0.05)$ at $25-36 \mathrm{~h}$. $\mathrm{T}_{3}$ concentrations increased at later intervals and approached the control value by $49-240 \mathrm{~h}$.

The concentration of free $\mathrm{T}_{4}$ in cord plasma (Fig. $2 c$ ) was also increased at $2-6 \mathrm{~h}$ after TRH treatment $(+19 \%$ versus control, NS after adjusting for multiple comparisons), and levels were slightly decreased $(84 \%$ of control) at $49-240 \mathrm{~h}$ after treatment.

When data for cord PRL were analyzed for all infants of 2634 wk gestation, there were no significant differences between control and treated groups (treated $2-6 \mathrm{~h} 88.3 \pm 22.5 \mu \mathrm{g} / \mathrm{L}$ versus control $67.6 \pm 5.3 \mu \mathrm{g} / \mathrm{L})$. However, because 12 of the 14 infants delivering $2-6 \mathrm{~h}$ after the last treatment were $\leq 30 \mathrm{wk}$ of gestational age, and because cord PRL increases markedly during gestation, we reanalyzed the data for infants of 26-30 wk (Fig. $2 d$ ). In these infants, PRL was increased more than 2-fold at 2$6 \mathrm{~h}$ after TRH treatment compared with control infants of 26$30 \mathrm{wk}$; values at subsequent intervals were not different from control.

To examine the response to repeated treatment with TRH, we analyzed data by the number of doses of TRH. Figure 3 shows data for $T_{3}$ and free $T_{4}$ at 2-6 $\mathrm{h}$ from last treatment (maximal stimulation) plotted versus the number of TRH doses. Although the number of samples is limited, the mean levels of both hormones are similarly increased after each dose of TRH. However, it is worth noting that three of the six infants delivered 2$6 \mathrm{~h}$ after the 4 th dose of TRH had $\mathrm{T}_{3}$ concentrations in the control range. Levels of cord PRL at $2-6 \mathrm{~h}$ were also similar 
Table 1. Concentrations of plasma thyroid hormones and prolactin in control population*

\begin{tabular}{|c|c|c|c|c|}
\hline \multirow[b]{2}{*}{ Hormone } & \multirow[b]{2}{*}{ Maternal } & \multirow[b]{2}{*}{ Cord } & \multicolumn{2}{|c|}{ Newborn } \\
\hline & & & $2 \mathrm{~h}$ & $24 \mathrm{~h}$ \\
\hline $\mathrm{TSH}(\mathrm{mU} / \mathrm{L})$ & $\begin{array}{c}4.0 \pm 0.2 \dagger \\
(62)\end{array}$ & $\begin{array}{c}9.7 \pm 0.7 \\
(61)\end{array}$ & $\begin{array}{c}15.0 \pm 1.2 \dagger \\
(51)\end{array}$ & $\begin{array}{c}8.9 \pm 1.1 \\
(51)\end{array}$ \\
\hline $\mathrm{T}_{3}(\mathrm{nmol} / \mathrm{L})$ & $\begin{array}{c}2.4 \pm 0.1 \dagger \\
(61)\end{array}$ & $\begin{array}{c}0.6 \pm 0.04 \\
(57)\end{array}$ & $\begin{array}{c}1.6 \pm 0.1 \dagger \\
(59)\end{array}$ & $\begin{array}{c}1.5 \pm 0.1 \dagger \\
(51)\end{array}$ \\
\hline Free $\mathrm{T}_{4}(\mathrm{pmol} / \mathrm{L})$ & $\begin{array}{c}11.2 \pm 0.6 \dagger \\
(61)\end{array}$ & $\begin{array}{c}14.5 \pm 0.5 \\
(62)\end{array}$ & $\begin{array}{c}19.3 \pm 0.9 \dagger \\
(53)\end{array}$ & $\begin{array}{c}8.7 \pm 0.9 \dagger \\
(49)\end{array}$ \\
\hline $\operatorname{PRL}(\mu \mathrm{g} / \mathrm{L})$ & $\begin{array}{c}119.9 \pm 11.6 \dagger \\
(63)\end{array}$ & $\begin{array}{c}67.6 \pm 5.3 \\
(61)\end{array}$ & $\begin{array}{c}85.7 \pm 8.7 \\
(50) \\
\end{array}$ & $\begin{array}{c}78.7 \pm 6.9 \\
(51) \\
\end{array}$ \\
\hline
\end{tabular}

$*$ Values are mean \pm SEM for control women and their infants at a gestational age of $26-34$ wk who delivered $\leq 10 \mathrm{~d}$ after entry into the trial. Number of samples assayed is shown in parentheses.

$\dagger p<0.01$ vs cord.
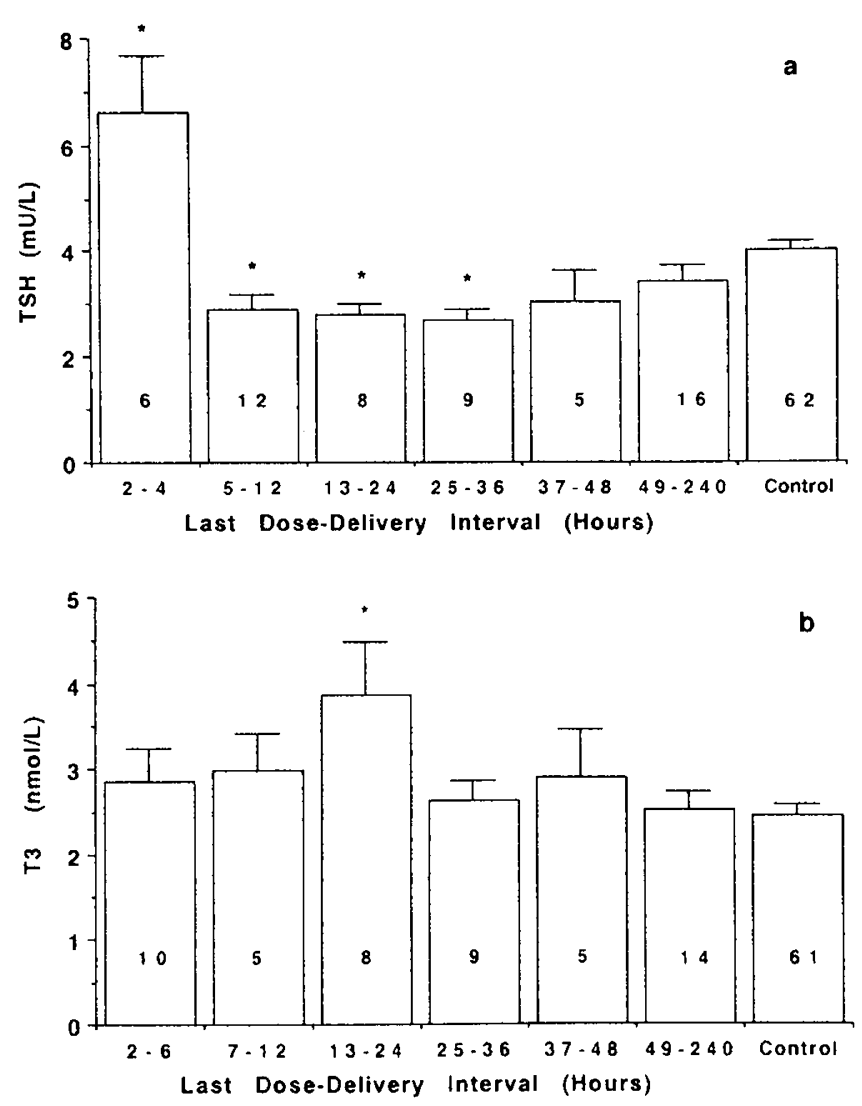

Fig. 1. Concentrations of TSH and $\mathrm{T}_{3}$ in plasma of women delivering at various intervals after the last dose of TRH. $a, \mathrm{TSH} ; b, \mathrm{~T}_{3}$. Values are mean $\pm \mathrm{SEM}$, and the number of samples is shown within the bars. *, $p$ $<0.05 \mathrm{vs}$ control. With correction for multiple comparisons, $p>0.05 \mathrm{vs}$ control for TSH values at $5-36 \mathrm{~h}$.

after each dose of TRH (range of mean values $80-120 \mu \mathrm{g} / \mathrm{L}$ ). There were too few values of TSH in the maximally stimulated group (2-4 h) for analysis by number of treatment doses.

We also attempted to analyze the effect of number of treatments on suppression of TSH and $\mathrm{T}_{3}$. However, because maximal suppression occurred among infants delivered 13-36 h after the last dose of TRH, all of these infants received either three or four (the majority) treatments. Thus, analysis by number of doses was not feasible.

Newborn concentrations after TRH. Blood samples were also obtained from most infants at $2 \mathrm{~h}$ of age, at the peak of the normal postnatal $T_{3}$ surge, and at approximately $24 \mathrm{~h}$ after delivery. Figure 4 shows the values for TSH at $2 \mathrm{~h}$ after birth as a function of the time from last TRH dose to delivery. TSH was significantly suppressed in infants delivered 13-48 h after treat- ment, but the level was similar to control for those delivering $49-240 \mathrm{~h}$ after the last dose. At $24 \mathrm{~h}$ of age, the concentration of TSH remained low in the group of infants delivered at 2-6 h after treatment $(3.3 \pm 0.6 \mathrm{mU} / \mathrm{L}, 37.1 \%$ of control) but values for the other treatment groups were not different from control.

Levels of $\mathrm{T}_{3}$ at $2 \mathrm{~h}$ of age were lower than control for treated infants delivering at 2-6 and 25-48 $\mathrm{h}$ after the last in utero treatment (Fig. $4 b$ ). The data for infants delivering 7-12 $\mathrm{h}$ and 13-24 $\mathrm{h}$ after the last dose were more variable, and mean values were not different from control. In samples obtained at $24 \mathrm{~h}$ after birth, $T_{3}$ remained suppressed in the 2- to 6-h group $(0.9 \pm$ $0.2 \mathrm{nmol} / \mathrm{L}, 60.5 \%$ of control) but was normal in the other groups.

Figure $4 c$ shows mean values of free $\mathrm{T}_{4}$ at $2 \mathrm{~h}$ of age. Compared with control, levels were slightly but significantly lower for most of the treatment interval groups. In samples obtained at $24 \mathrm{~h}$ of age, free $\mathrm{T}_{4}$ remained less than control for the four treatment groups through $48 \mathrm{~h}(69-79 \%$ of control) but was normal for infants of 49- to 240-h treatment interval.

We further analyzed hormone concentrations after birth by calculating the incremental change from the corresponding value in cord blood. These data are presented in Table 2 for control and treated infants delivering at various intervals after the last in utero dose. For TSH, control infants had an average increase of $6.5 \mathrm{mU} / \mathrm{L}$ between birth and $2 \mathrm{~h}$ of age. By contrast, treated infants delivering at $2-6 \mathrm{~h}$ after the last TRH dose had a decrease of approximately $2 \mathrm{mU} / \mathrm{L}$. A similar pattern occurred with $\mathrm{T}_{3}$, with control infants having a postnatal increase of $\sim 1.1 \mathrm{nmol} /$ $\mathrm{L}$, whereas in treated infants delivered at $2-6 \mathrm{~h}$ there was a decrease after birth of $\sim 0.3 \mathrm{nmol} / \mathrm{L}$. Infants delivered at later times after the last dose increased their $T_{3}$ concentrations similar to controls. The pattern was similar for free $T_{4}$ with an increase in control infants and a decrease or minimal increase for treated infants delivered at 2-48 h.

Postnatal concentrations of PRL were similar in all of the treatment groups (range $50.2-114.3 \mu \mathrm{g} / \mathrm{L}$ ) and were not significantly different from the control value. As expected, there was no difference between postnatal and cord values of PRL for either control (Table 1) or treated infants (data not shown).

\section{DISCUSSION}

In this study, we assayed concentrations of thyroid hormones and PRL in blood samples obtained from pregnant women and their premature infants who were enrolled in a multicenter trial of antepartum TRH plus glucocorticoid for prevention of newborn lung disease. In this trial, TRH treatment significantly reduced the incidence of chronic lung disease, defined as continuing requirement for supplemental oxygen at $28 \mathrm{~d}$ of life (20). The clinical benefit of prenatal TRH is supported by the report of Morales et al. (17) and by other preliminary observations (23, 24; D. Knight, G. C. Liggins, unpublished observations). Because this form of therapy may become a generally accepted treatment 

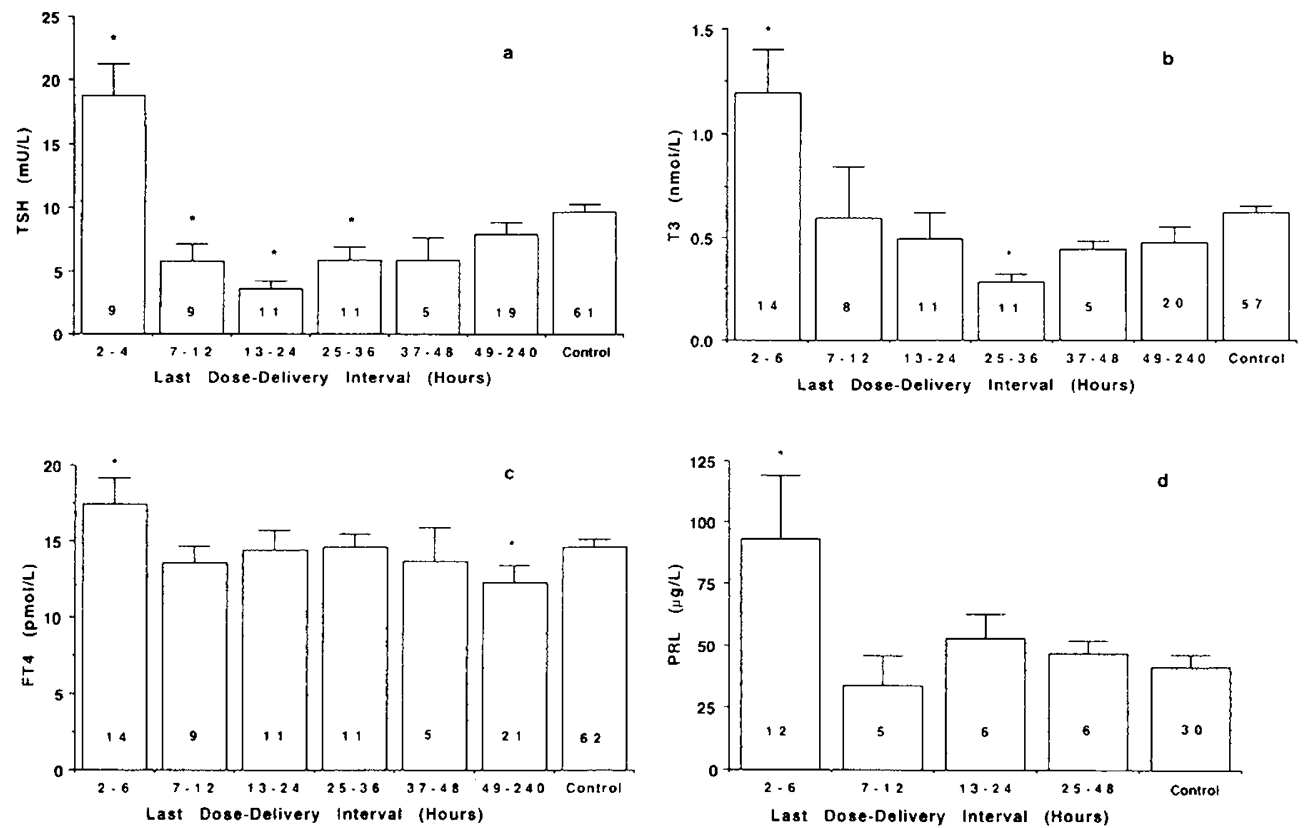

Fig. 2. Concentration of hormones in cord plasma of treated and control infants delivered at various intervals after the last dose of TRH. The gestational age range was 26-34 wk except for analysis of PRL, where the range was 26-30wk. $a$, TSH; $b, \mathrm{~T}_{3} ; c$, free $\mathrm{T}_{4} ; d, \mathrm{PRL}$. Values are mean $\pm \mathrm{SEM}$, and the number of samples is shown within the bars. ${ }^{*}, p<0.05 v s$ control. With correction for multiple comparisons, $p>0.05 v s$ control for TSH values at 7-12 and $25-36 \mathrm{~h}$ and for $\mathrm{T}_{4}$ values at $2-6$ and $49-240 \mathrm{~h}$.
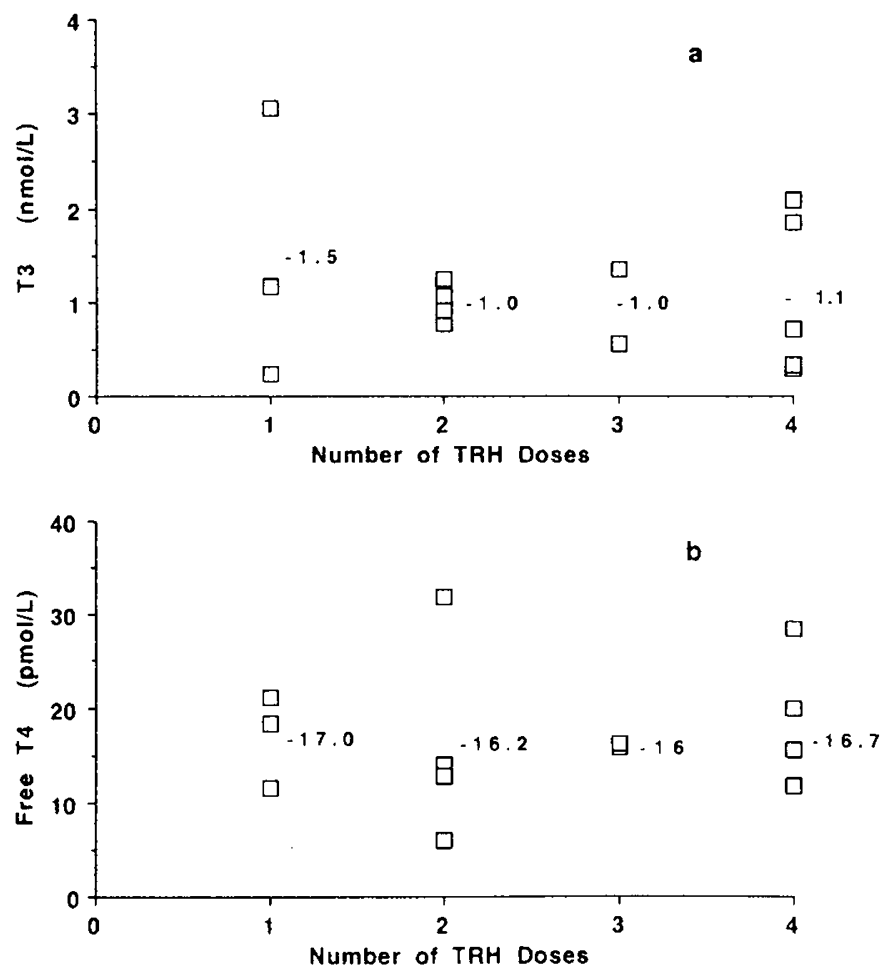

Fig. 3. Cord plasma $T_{3}$ and free $T_{4}$ for infants delivered $2-6 \mathrm{~h}$ after the last dose of TRH: effect of the number of treatments. Individual data and mean values are shown for $T_{3}(a)$ and free $T_{4}(b)$ for infants delivered at 2-6 $\mathrm{h}$ after one, two, three, or four doses of maternal TRH. Hormone concentrations in the corresponding control population are shown in Table 1: for $\mathrm{T}_{3}, p=<0.001,0.006,0.09$, and $0.007 \mathrm{vs}$ control at one, two, three, and four doses, respectively; for free $\mathrm{T}_{4}, p=0.24,0.42,0.55$, and 0.01 at one, two, three, and four doses, respectively. regimen for women in premature labor, we felt it was important to further investigate the effects of TRH on hormone concentrations in the premature infant.

Although we did not have an untreated group in this study, there were no time-dependent changes in thyroid hormone or PRL concentrations in cord blood of the population treated with betamethasone alone (control), and values in cord blood were similar to earlier results for untreated infants (22, 25-29), suggesting that betamethasone did not affect hormone levels. Previously, Osathanondh et al. (25) reported increased cord levels of $T_{3}$ and reverse $T_{3}$ after maternal dexamethasone treatment at term, but no differences were observed with betamethasone therapy before preterm delivery (12). We found no developmental increase in concentrations of TSH in cord plasma at 26$34 \mathrm{wk}$, in agreement with the findings of Fisher et al. (22) but differing from the recent results of Thorpe-Beeston et al. (27). The earlier observations of relatively low concentrations of circulating $\mathrm{T}_{3}$ in the premature fetus plus the observed effects of thyroid hormones on lung maturation in animals and cultured tissue (12) provided the rationale for the clinical study of TRH treatment.

To our knowledge, this study provides the first description of the extended time course of exogenous TRH effects on thyroid hormone concentrations in the premature fetus. We found that the maximal increase of both TSH and $\mathrm{T}_{3}$ was about 2 -fold in cord compared with $\sim 50 \%$ in corresponding maternal samples. The maximal fold increase in TSH is less than that previously reported (15-19), likely reflecting the transient nature of the TSH rise and the fact that none of our samples was from infants born less than $2 \mathrm{~h}$ after the last dose of TRH. The mean values for $\mathrm{T}_{3}$ and free $T_{4}$ in our study were comparable whether infants delivered after the 1st, 2nd, 3rd, or 4th dose of TRH. The apparent persistence of responsiveness to TRH is in agreement with studies in fetal monkeys in which pretreatment of the fetuses with $\mathrm{T}_{3}$ did not blunt TRH-stimulated increases in TSH (30).

The increase in fetal $T_{3}$ and free $T_{4}$ after in utero $T R H$ can be considered physiologic in that the maximal levels achieved after treatment are comparable to those normally occurring after birth. Because $\mathrm{T}_{3}$ concentrations in cord plasma returned to control values by approximately $12 \mathrm{~h}$ after treatment, the repeated 

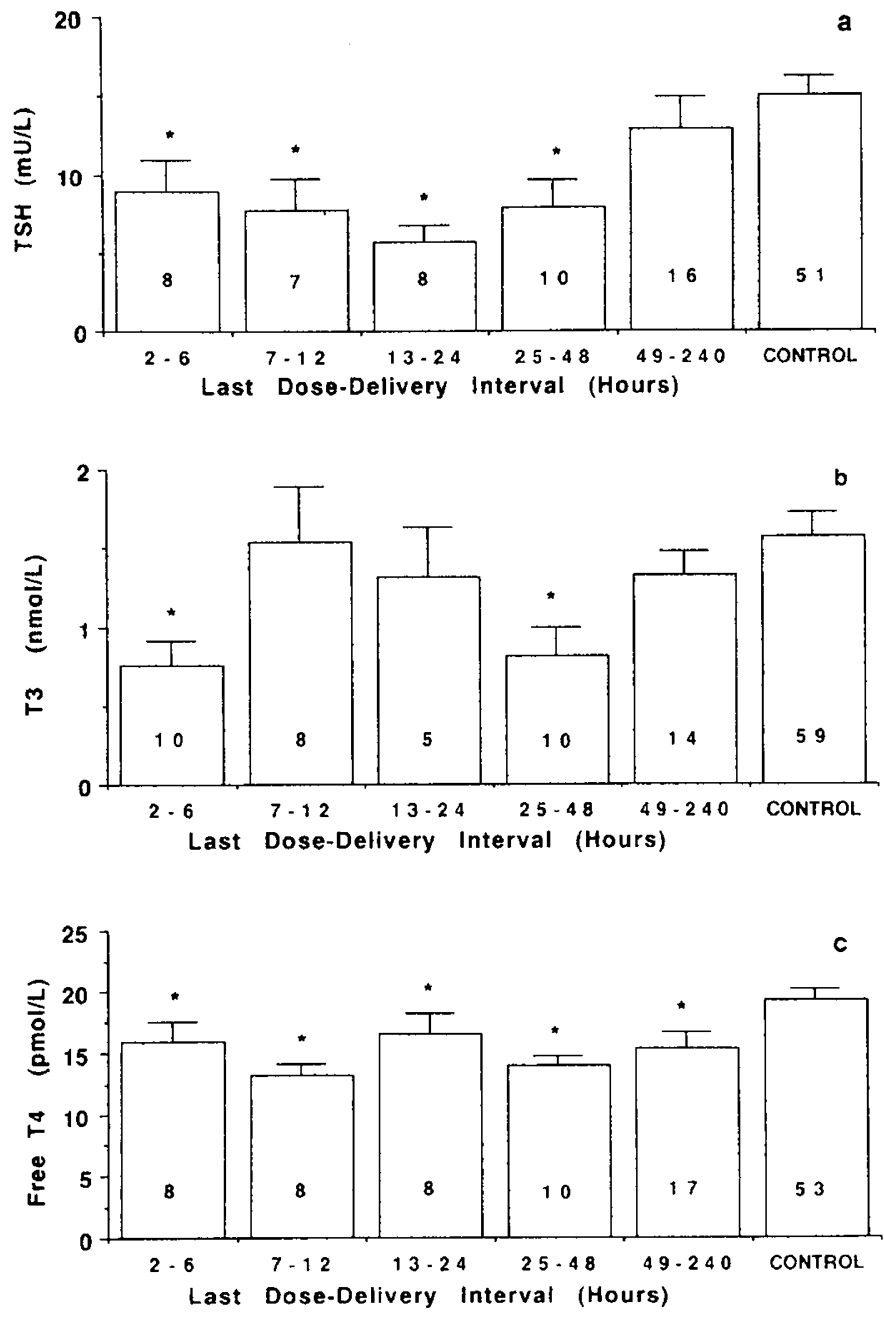

Fig. 4. Plasma hormones at $2 \mathrm{~h}$ after birth in infants delivered at various times after the last dose of TRH. $a, \mathrm{TSH} ; b, \mathrm{~T}_{3} ; c$, free $\mathrm{T}_{4}$. Values are mean \pm SEM, and the number of samples is shown within the bars. *, $p<0.05$ vs control. With correction for multiple comparisons, $p>$ 0.05 vs control for TSH values at $2-12 \mathrm{~h}$ and for free $T_{4}$ values at 2-6 and $13-24 \mathrm{~h}$.

injections of TRH on an 8-h schedule likely do not result in increasingly higher concentrations of plasma $T_{3}$ and $T_{4}$ with each dose. However, intracellular concentrations of receptor-hormone complex probably remain elevated in target tissues throughout the treatment period of at least $24 \mathrm{~h}$ due to the longer $t_{1 / 2}$ for $T_{3}$ in tissue versus plasma. Based on responses to $T_{3}$ in experimental systems, this exposure time should be sufficient to maximally induce target proteins. Of interest, the clinical benefit of TRH treatment in this study was apparent only in those infants delivering at least $24 \mathrm{~h}$ after the first dose (19). The mechanism for reduced chronic lung disease after TRH treatment is uncertain but could involve accelerated development of lung structure, surfactant production, and/or fluid resorption.

Theoretical concerns regarding prenatal TRH treatment are thyrotoxicosis and alterations in learning, behavior, and the pituitary-thyroid axis as have been observed after $T_{4}$ treatment of newborn rats. However, the risk of these effects in infants seems low inasmuch as the increase in thyroid hormone concentrations is relatively brief and within the physiologic range. In adults, thyrotoxicosis after TRH is rare and only observed with prolonged treatment (31).

The effect of TRH treatment on concentrations of cord PRL has been controversial. Moya et al. (18) found a doubling of cord PRL in infants of 27-34 wk of gestation, whereas Roti et al. (19) and Miyamoto (32) found no effect of TRH on PRL $1 \mathrm{~h}$ after treatment of women at $\sim 36 \mathrm{wk}$ of gestation and term, respectively. In this study, we found a transient increase in PRL when the comparison was restricted to infants of $26-30 \mathrm{wk}$ of gestation. These various observations suggest that PRL is stimulated by TRH only in the less mature fetuses. It is possible that fetuses closer to term are also responsive, but that the effect is more difficult to observe due to the greater variability of basal levels as gestation proceeds. The failure to observe an increase in maternal PRL as previously reported (29) probably reflects the rapid (maximal at $20 \mathrm{~min}$ ) and transient increase in their hormone. The possible role of PRL in the beneficial effects of TRH treatment for the premature infant remains uncertain. Although PRL has a permissive role in cortisol effects on lung maturation in the immature fetal lamb (6), a similar effect of PRL in other species, including cultured human lung, has not been established (12).

Previously, Morales et al. (17) observed that the mean value for TSH in patients delivering at 1-7 d after TRH treatment was significantly lower than control for both cord and maternal serum, whereas cord levels of $\mathrm{T}_{3}$ and $\mathrm{T}_{4}$ were normal. Our data confirm the observation of decreased TSH, indicate that $T_{3}$ is also transiently suppressed, and establish the time course for both hormones. Suppression was greater in the fetus than in the mother in whom TSH was only slightly decreased at 5-36 h after treatment and no suppression occurred for $T_{3}$ and free $T_{4}$. The suppression of TSH after repetitive TRH treatments of pregnant women is in general agreement with earlier observations in adult men and nonpregnant women in whom repetitive TRH treatments decreased basal TSH by approximately 33\% (33) and greatly reduced the TSH response to TRH stimulation $(31,33)$. This suppression has been generally attributed to feedback inhibition of TSH production by the elevated endogenous $\mathrm{T}_{3}$ and $\mathrm{T}_{4}$ after TRH stimulation. The reason that the suppression is more marked in the fetus than in the adult is not certain but may be related to the greater increase in fetal versus maternal $\mathrm{T}_{3}$ levels. This mechanism is supported by earlier data that intraamniotic

Table 2. Incremental changes in thyroid hormone levels after birth*

Concentration at $2 \mathrm{~h}$ of age minus concentration in cord blood

\begin{tabular}{|c|c|c|c|c|c|c|}
\hline & \multicolumn{6}{|c|}{ Concentration at $2 \mathrm{~h}$ of age minus concentration in cord blood } \\
\hline & $\begin{array}{c}0 \dagger \\
\text { (control) }\end{array}$ & $2-6 \dagger$ & $7-12 \dagger$ & $13-24 \dagger$ & $25-48 \dagger$ & $49-240 \dagger$ \\
\hline $\mathrm{TSH}(\mathrm{mU} / \mathrm{L})$ & $\begin{array}{c}6.5 \pm 1.2 \\
(45)\end{array}$ & $-1.8 \pm 1.1 \ddagger$ & $1.7 \pm 1.8$ & $1.8 \pm 1.2$ & $\begin{array}{c}5.4 \pm 3.8 \\
(9)\end{array}$ & $\begin{array}{c}4.5 \pm 1.8 \\
(16)\end{array}$ \\
\hline $\mathrm{T}_{3}(\mathrm{nmol} / \mathrm{L})$ & $\begin{array}{c}1.1 \pm 0.1 \\
(45)\end{array}$ & $-0.3 \pm 0.3 \ddagger$ & $\begin{array}{c}0.6 \pm 0.2 \\
(6)\end{array}$ & $\begin{array}{c}0.6 \pm 0.2 \\
(9)\end{array}$ & $\begin{array}{c}0.5 \pm 0.2 \\
(10)\end{array}$ & $\begin{array}{c}0.7 \pm 0.2 \\
(13)\end{array}$ \\
\hline Free $\mathrm{T}_{4}(\mathrm{pmol} / \mathrm{L})$ & $\begin{array}{c}5.0 \pm 1.0 \\
(42)\end{array}$ & $-1.8 \pm 1.2 \ddagger$ & $\begin{array}{c}-0.8 \pm 1.1 \ddagger \\
(6)\end{array}$ & $1.2 \pm 1.3$ & $\begin{array}{c}-0.9 \pm 1.6 \\
(9)\end{array}$ & $\begin{array}{c}0.23 \pm 0.12 \\
(15)\end{array}$ \\
\hline
\end{tabular}

* Incremental change after birth for the concentration of each hormone was calculated. Mean \pm SEM values are shown for infants delivering at various intervals after the last prenatal dose of TRH and for control infants ( 0 time). The number of samples assayed is shown in parentheses.

$\dagger$ Last dose-delivery interval.

$\ddagger p<0.05$ vs control. 
injection of $\mathrm{T}_{4}$ decreased basal TSH concentration in cord blood and reduced the postnatal increase in TSH (22).

We also examined the effect of prenatal TRH on the postnatal surge in thyroid hormones. Infants who were born 13-48 h after the last dose of prenatal TRH had significantly decreased postnatal TSH concentrations compared with controls. This finding appears to represent the suppression of TSH (observed in utero) plus failure to normally increase TSH after birth (Table 2). In those infants delivered at 2-6 $\mathrm{h}$ after treatment, TSH remained below the control level at $24 \mathrm{~h}$ of age.

Concentrations of $T_{3}$ at $2 \mathrm{~h}$ of age were also decreased in recently treated fetuses; however, infants born more than $7 \mathrm{~h}$ after the last $\mathrm{TRH}$ dose increased their $\mathrm{T}_{3}$ postnatally in a manner similar to control infants. For recently treated infants $(2-6 \mathrm{~h})$, plasma concentrations of both TSH and $\mathrm{T}_{3}$ decreased from the value at birth rather than increasing. In the study of Moya et al. (18), there was a normal postnatal increase in $\mathrm{T}_{3}$ after one dose of TRH. Our findings suggest that the pituitary-thyroid axis in recently treated newborn infants is either unresponsive to TRH or that the normal increase in endogenous TRH after birth is suppressed. Although the duration of the postnatal suppression in this group of infants remains to be determined, it is most likely transient in view of the time course in utero. Postnatal hypothyroxinemia has been described in premature infants and has been ascribed to hypothalamic immaturity. This condition is transient $(\sim 6 \mathrm{wk})$ and appears to be benign with regard to intellectual development (26).

In summary, maternal TRH treatment produces a transient increase in fetal thyroid hormones and PRL to maximal levels approximating those achieved at term or after birth in the premature infant. The kinetics of the increase indicate that TRH treatment should maintain elevated tissue levels of thyroid hormones for at least $24 \mathrm{~h}$. At later times after treatment, fetal thyroid hormones are suppressed, and infants born during the early phase of suppression do not develop the normal postnatal surge of thyroid hormones. The duration of this postnatal suppression remains to be determined.

Acknowledgments. The authors thank Madeleine Huey for performing the assays and the obstetrical and neonatal nurses, residents, and fellows at Mt. Zion Hospital, Harbor-UCLA Medical Center, and University of Texas at Houston Medical Center for assistance in collecting blood samples and patient data.

\section{REFERENCES}

1. Gross I, Dynia DW, Wilson CM, Ingelson LD, Gewolb IH, Rooney SA 1984 Glucocorticoid-thyroid interactions in fetal rat lung. Pediatr Res 18:191-196

2. Ballard PL, Hovey ML, Gonzales LK 1984 Thyroid hormone stimulation of phosphatidylcholine synthesis in cultured fetal rabbit lung. J Clin Invest 74:898-905

3. Gonzales LW, Ballard PL, Ertsey R, Williams MC 1986 Glucocorticoids and thyroid hormones stimulate biochemical and morphological differentiation of human fetal lung in organ culture. J Clin Endocrinol Metab 62:687-691

4. Liggins GC, Shellenberg JC, Manzai M, Kitterman JA, Lee CCH 1988 Synergism of cortisol and thyrotropin releasing hormone on lung maturation in fetal sheep. J Appl Physiol 65:1880-1884

5. Boshier CP, Holloway H, Liggins GC, Marshall RJ 1989 Morphometric analyses of the effects of thyrotropin releasing hormone and cortisol on the lungs of fetal sheep. J Dev Physiol 12:49-54

6. Shellenberg JC, Liggins GC, Manzai MK, Kitterman JA, Lee CCH 1988 Synergistic hormonal effects on lung maturation in fetal sheep. J Appl Physiol 65:94-100

7. Warburton D, Parton L, Buckley S, Cosico L, Enns G, Saluna T 1988 Combined effects of corticosteroid, thyroid hormones, and $\beta$-agonist on surfactant, pulmonary mechanics and $\beta$-receptor binding in fetal lamb lung. Pediatr Res 24:166-170

8. Devaskar U, Nitta K, Szewczyk K, Sadiq HF, deMello D 1987 Transplacental stimulation of functional and morphologic fetal rabbit lung maturation: effect of thyrotropin-releasing hormone. Am J Obstet Gynecol 157:460-464

9. Oulton M, Rasmusson MG, Yoon RY, Fraser M 1989 Gestation-dependent effects of the combined treatment of glucocorticoids and thyrotropin-releasing hormone on surfactant production by fetal rabbit lung. Am J Obstet Gynecol 160:961-967

10. Barker PM, Markiewicz M, Parker KA, Walters DV, Strang LB 1990 Synergistic action of triiodothyronine and hydrocortisone on epinephrine-induced reabsorption of fetal lung liquid. Pediatr Res 27:588-591

11. Ikegami M, Jobe AH, Pettenazo A, Seidner SR, Berry DD, Ruffini L 1987 Effects of maternal treatment with corticosteroids, $T_{3}$, TRH and their combinations on lung function of ventilated preterm rabbits with and without surfactant treatments. Am Rev Respir Dis 136:892-898

12. Ballard PL 1986 Hormones and Lung Maturation. Monographs on Endocrinology, Vol 28. Springer-Verlag, New York

13. Mashiach S, Barkai G, Sack J, Stern E, Goldman B, Brish M, Serr DM 1978 Enhancement of fetal lung maturity by intra-amniotic administration of thyroid hormone. Am J Obstet Gynecol 130:289-293

14. Schreyer P, Caspi E, Letko Y, Ron-El R, Pinto N, Zeidman JL 1982 Intraamniotic triiodothyronine instillation for prevention of respiratory distress syndrome in pregnancies complicated by hypertension. J Perinat Med 10:2731

15. Roti E, Gnudi A, Braverman LE, Robuschi G, Emanuele R, Bandini P, Benassi L, Pagliani A, Emerson CH 1981 Human cord blood concentrations of thyrotropin-releasing hormone. J Clin Endocrinol Metab 53:813-817

16. Moya F, Mena P, Heusser F, Forafori A, Paiva E, Yazigi R, Michaud P, Gross I 1986 Response of the maternal, fetal and neonatal pituitary-thyroid axis to thyrotropin-releasing hormone. Pediatr Res 20:982-986

17. Morales WJ, O'Brien WF, Angel JL, Knuppel RA, Sawai S 1989 Fetal lung maturation: the combined use of corticosteroids and thyrotropin-releasing hormone. Obstet Gynecol 73:111-116

18. Moya F, Mena P, Foradori A, Becerra M, Inzunza A, Germain A 1991 Effect of maternal administration of thyrotropin releasing hormone on the preterm fetal pituitary-thyroid axis. J Pediatr 119:966-971

19. Roti E, Gardini E, Minelli R, Bianconi L, Alboni A, Braverman LE 1990 Thyrotropin releasing hormone does not stimulate prolactin release in the preterm human fetus. Acta Endocrinol (Copenh) 122:462-466

20. Ballard RA, Ballard PL, Creasy RK, Padbury J, Polk DH, Bracken M, Moya FR, Gross I 1992 Respiratory disease in very-low-birthweight infants after prenatal thyrotropin-releasing hormone and glucocorticoid. Lancet 339:510515

21. Ballard RA, Ballard PL, Creasy R, Gross I, Moya FR, Padbury JF 1991 Thyroid hormone and prolactin levels in premature infants exposed to thyrotropin-releasing hormone in utero. Pediatr Res 29:307A (abstr)

22. Fisher DA, Dussault JH, Sack J, Chopra IJ 1977 Ontogenesis of hypothalamicpituitary-thyroid function and metabolism in man, sheep and rat. In: Recent Progress in Hormone Research, Vol 33. Academic Press, New York, pp 59116

23. Jikihara H, Sawada Y, Imai S, Morishige K, Taniguchi $\Upsilon$, Nohara A, Lynn S, Miyanishi K, Shimizu I, Sumida H, Fujimura M, Suehara N, Takeuchi T 1990 Maternal administration of thyrotropin-releasing hormone for prevention of neonatal respiratory distress syndrome. Proceedings of the 6th Congress of the Federation of Asia-Oceana Perinatal Societies, Perth, West Australia, (abstr 87)

24. Althabe F, Fustinana C, Althabe O, Ceriani Cernadas JM 1991 Controlled trial of prenatal betamethasone plus TRH $v s$ betamethasone plus placebo for prevention of RDS in preterm infants. Pediatr Res 29:200A (abstr)

25. Osathanondh R, Chopra IJ, Tulchinsky D 1978 Effects of dexamethasone on fetal and maternal thyroxine, triiodothyronine, reverse triiodothyronine and thyrotropin levels. J Clin Endocrinol Metab 47:1236-1239

26. Hadeed AJ, Asay LD, Klein AH, Fisher DA 1981 Significance of transient postnatal hypothyroxinemia in premature infants with and without respiratory distress syndrome. Pediatrics 68:494-498

27. Thorpe-Beeston JG, Nicolaides KH, Felton CV, Butler J, McGregor AM 1991 Maturation of the secretion of thyroid hormone and thyroid stimulating hormone in the fetus. N Engl J Med 324:532-536

28. Gluckman PD, Ballard PL, Kaplan SL, Liggins GC, Grumbach MM 1978 Prolactin in umbilical cord blood and the respiratory distress syndrome. $\mathbf{J}$ Pediatr 93:1011-1014

29. Ylikorkala O, Kivinen S, Reinila M 1979 Serial prolactin and thyrotropin responses to thyrotropin-releasing hormone throughout normal human pregnancy. J Clin Endocrinol Metab 48:288-292

30. Melmed S, Harada A, Murata Y, Socol M, Reed A, Carlson HE, Azukizawa M, Martin C, Jorgensen E, Hershman JM 1979 Fetal response to thyrotropinreleasing hormone after thyroid hormone administration to the rhesus monkey: lack of pituitary suppression. Endocrinology 105:334-341

31. Staub JJ, Girard J, Mueller-Brand J, Noelpp B, Werner-Zodrow I, Baur U, Heitz PH, Gemsenjaeger E 1978 Blunting of TSH response after repeated oral administration of TRH in normal and hypothyroid subjects. $\mathbf{J}$ Clin Endocrinol Metab 46:260-266

32. Miyamoto $\mathbf{J} 1984$ Prolactin and thyrotropin responses to thyrotropin-releasing hormone during the peripartal period. Obstet Gynecol 63:639-644

33. Snyder PJ, Utiger RD 1973 Repetitive administration of thyrotropin-releasing hormone results in small elevations of serum thyroid hormones and in marked inhibition of thyrotropin response. J Clin Invest 52:2305-2312 